\title{
SUPERVISI KLINIS BAGI CALON GURU DALAM PROGRAM PENGALAMAN LAPANGAN (PPL) Oleh Suhardi Marli ${ }^{1}$
}

\begin{abstract}
Abstrak: Usaha untuk memberikan bantuan berupa bimbingan kepada mahasisawa calon guru dalam PPL merupakan sesuatu yang mutlak yang harus dilakukan oleh pembimbing (dosen pembimbing dan guru pamong). Salah satu komponen penting dalam roses bimbingan tersebut adalah Supervisi Klinis.Hal ini sangat penting dilakukan mengingat calon gurumerupakan orang yang harus dipersiapkan untuk menjadi guru, dimana guru harus menguasai empat kopetensi guru. Dalam pelaksanaannya supervisi klinis memberikan bantuan bimbingan kepada calon guru sesuai dengan kebutuhan calon guru yang bersangkutan sehingga pada akhirnya calon guru mampu menemukan sendirikelemahan yang ada pada dirinya dan akhirnya dia mampu untuk meningkatkan dirinya melalui analisis bersama dalam kegiatan supervisi klinis.
\end{abstract}

\section{Kata Kunci: Supervisi Klinis, Calon Guru}

\section{A. Pendahuluan}

Kemampuan mengajar memerlukan seperangkat pengetahuan dan keterampilan tertentu agar calon guru dapat melaksanakan tugasnya dengan semestinya. Kemampuan mengajar itu mulai dibentuk dilembaga pendidikan guru, dan selanjutnya dikembangkan melalui pembinaan dalam jabatan dilapangan, yang dapat dilakukan dengan usaha mandiri maupun dengan bantuan orang lain. Pekerjaan memberi bantuan disebut supervisi dan pemberi bantuan disebut supervisor. Untuk latar penyelangaraan Program Pengalaman Lapangan, utamanya latihan praktek mangajar di sekolah, supervisi tersebut dilakukan oleh dosen pembimbing dan guru pamong. Terdapat beberapa alasan yang menjadi dasar pentingnya supervisi dalam latihanpraktek mengajar untuksetiap calon guru, antara lain: (1) calon guru memiliki kemampuan yang terbatas untuk mengendalikan dan menganaslisis tingkah laku siswanya dalam proases pembelajaran, dan (2) proses pembelajarana adalah sesuatu yang kompleks dan rumit sehingga guru sulit memisahkan, merefleksikan dan menyadari tingkah lakunya selama

${ }^{I}$ Suhardi Marli : adalah dosen Jurusan Pendidikan Dasar FKIP UNTAN 
mengelola proses pembelajaran (Sulo La Sulo, dkk, 1995: 1). Oleh karena itu, supervisor akan sangat membentu mahasiswa calon guru dalam meningkatkan kemampuan mengajarnya dengan membentu mengobservasi, merefleksi, dan menganalisis tingkah laku mengajarnya itu.

Meskipun supervisi itu sangat penting dalam upaya peningkatan kemampuan profesional calon guru, namun seringkali calon guru kurang menyukai supervisi tersebut. Keengganan terhadap supervisis tersebut pada umumnya bersumber dari gaya supervisi yang diterimanya selama ini (Bolla, 1985:2) yakni :

1. Supervisi diidentikan dengan evaluasi, sehingga calon guru cendrung resah dan menolak supervisi tersebut(baik secara terang-terangan maupun secara terselubung).

2. Calon guru kurang merasakan manfaat supervisi, karena supervisi tersebut tidak didasarkan pada kebutuhannya.

3. Sasaran pengamatan supervisis terlalu luas dan bersifat umum, sehingga sukar memberikan balikan yang dan bermanfaat bagi peningkatan kemampuan mengajar calon guru.

4. Pemberian balikan sering menjadi pemberian pengarahan bahkan serangkaian instruksi, dan tidak melibatkan calon guru dalam menganalisis dirinya untuk mencari cara pengembangan dirinya.

Gaya supervisi yang tradisional tersebut tidak memadai untuk menumbuhkan sikap dan kemampuan profesional calon guru, yakni guru yang mau dan mampu meningkatkan dirinya.Pada akhir dasawarsa lima tahunan dan awal dasawarsa enam puluhan dikembangkan suatu pendekatan atau gaya baru dalam supervisi oleh Morris Cogan, Robert Goldammer, dan kawankawannya di Harvard School of Education. Pendekatan atau gaya supervisi tersebut diberi nama Supervisi Klinis (Clinical Supervition), dengan penekanan pada hubungan tatap muka (fase to fase) antara supervisor dengan yang dibimbing (calon guru) serta terpusat pada tingkah laku aktual calon guru dalam mengajar.

Meskipun digunakan kata Klinis tetapi tidak terbatas hanya pada usaha perbaikan atau remidial saja, karena dengan supervisi klinis dapat dapat pula dikembangkan kemampuan mengajar itu. Pendekatan supervisi klinis ini pada awal tahun delapan puluhan diperkenalkan di Indonesia melalui Tim pengembangan Program Pengalaman Lapangan dari proyek Pengembangan Pendidikan Guru (P3G), dan selanjutkan dimantapkan melalui Proyek 
Pengembangan Lembaga Pendidikan Tenaga Kependidikan (P2LPTK). Pendekatan itu telah dilaksanakan diberbagai LPTK dalam bimbingan mahasiswa calon guru yang melaksanakan latihan praktek mengajar. Namun masih dipandang pendekatan itu dimantapkan lagi tentang cara-cara pelaksanaannya agar dapat didayagunakan secara optimal.

\section{B. Pengertian Supervisi Klinis}

Taufik Sabirin (2009: 3) mengatakan bahwa, supervisi klinis adalah suatu proses bimbingan yang bertujuan untuk membantu pengembangan profesional guru dalam pelaksanaan proses pembelajaran. Bimbingan diarahkan pada upaya pemberdayaan guru dalam menguasai aspek teknis pembelajaran. Dengan bimbingan tersebut diharapkan terjadi terjadi peningkatan kualitas pembelajaran.

Pelaksanaan supervisis klinis menuntut perubahan paradigma calon guru dan dan supervisor. Supervisi dilakukan bukan dalam kontek mencari kesalahan dan kelemahan calon guruyang disupervisi. Antara calon guru dan supervisor adalah mitra sejajar, bukan merupakan antara bawahan dan atasan dan atau hubungan anatar guru dengan murid. Secara kemitraan keduanya menganalisis proses pembelajaran yang telah dirancang dan disepakati, kemudian dicarikan alternatif pemecahan masalah yang ditemui dalamproses pembelajaran tersebut agar ditingkatkan kualitasnya.

Richard Waller dalam La Sulo (1983:27) mengatakan :

"Clinical supervisition may be defined as supervition focused upon the inprovement of instruction by means of sistematic cycles of planning, observation and intensive intelectual analysis of actual teaching performance in the interest of rational modification"

Pendapat Richard di atas mengenai supervisi klinis memfokuskan pada upaya perbaikan proses pembelajaran yang dilakukan bersiklus. Perbaikan itu dilaksanakan secara berkelanjutan beberapa siklus sampai kondisi yang diinginkan dapat tercapai. Supervisi klinis diharapkan juga dapat melahirkan re-invation atau inovasi yang relevan dengan kultur dan kondisi masingmasing sekolah.

Supervisi klinis dapat dilakukan atas permintaan calon guru, karena ia merasakan belum mampu melaksankan strategi atau keterampilan mengajar tertentu, atau calon guru menemui masalah dalam proses pembelajaran yang ia tidak mampu mengatasinya sendiri. Calon guru juga dapat meminta agar 
ia disupervisi dengan supervisi klinis, karena ia merasa kurang maksimal dalam pelaksanaan proses pembelajaran.

Supervisi klinis juga dapat dilakukan atas permintaan kepala sekolah dan atau tim yang ditunjuk oleh kepala sekolah.Hasil supervisi memberikan petunjuk bahwa calon guru maupun guru tertentu perlu bantuan dan bimbingan agar mampu melaksanakan proses pembelajaran yang lebih berkualitas dan bermakna.

\section{Tujuan dan Ciri-Ciri Supervisi Klinis}

Dari pengertian supervisi klinis tersebut di atas ternyata pemberian bimbingan berbentuk bantuan sesuai kebutuhan mahasiswa calon guru yang bersangkutan, dan dilakukan dengan berbagai upaya (observasi secara sistematis, analisis data balikan dll) sehingga mahasiswa calon guru meneukan sendiri cara-cara meningkatkan dirinya melalui analisis bersama. Di dalam kata "klinis" tersirat cara kerja dibidang medis, dimana pihak yang memerlukan pertolongan itu datang atas prakarsa sendiri karena menyadari akan sesuatu kekurangan. (gangguan kesehatan), dianalisis berdasarkan keluhan-keluhan pasien dan pada akhirnya diberikan terapi. Di dalam supervisi klinis, bimbingan diberikan atas prakarsa calon guru, diobservasi dan dianalisis bersama untuk menemukan cara-cara yang tepat untuk menyempurnakan kekurangan-kekurangan yang masih ada dalam suatu keterampilan mengajar yang dilatihkan itu, untuk latihanberikutnyadan seterusnya. Pengertian "klinis" di dalam supervisi klinis menentukan bahwa bimbingan itu antara lain :

1. Dilaksanakan dalam satu hubungan tatap muka antara supervisor dan calon guruyang intimdan terbuka,

2. Terpusat pada kebutuhan/ kerisauan (concern) calon guru,

3. Observasi dilakukan secara langsung dan cermat,

4. Data observasi terpusat pada tingkah laku aktual calon guru sewaktu mengajar dan dideskripsikan secara rinci ,

5. Analisis dan interpretasi data hasil observasi dilakukan secara bersama serta,

6. Berlangsung sebagai pemberian bantuan, bukannya intruksi.

Supervisi Klinis bertujuan membimbing mahasiswa calon guru membentuk berbagai keterampilan mengajar, menyempurnakan berbagai kekurangan, serta mengembangkan keterampilan mengajar itu selanjutnya. 
Berdasarkan pengertian dan tujuan supervisi klinis tersebut di atas, maka terdapat beberapa ciri-ciri esensial supervisi klinis menurut Sulo La Sulo (1995:6) sebagai berikut :

a. Bimbingan di dalam supervisi bersifat bantuan, bukan perintah atau instruksi, sehingga prakarsa dan tanggung jawab mengembangkakan diri tetap ditangan mahasiswa sendiri

b. Meskipun calon guru di dalam latihan praktek mengajar menggunakan berbagai keterampilan mengajar secara terintegrasi, tetapi sasaran supervisi tidak dibatasi hanya pada satu atau dua keterampilan saja.

c. Sasaran supervisis diajukanoleh mahasiswa calon guru dan dikaji bersama untuk dijadikan kesepakatan (kontrak).

d. Instrumen observasi dikaji dan ditetapkan dalampertemuan antara supervisordan calon guru serta pengembangannya berdasarkan atas sasaran.

e. Balikan yang objektif dan spesifik diberikan dengan segera

f. Analisis dan interpretaasi data haasil observasi data hasil observasi

g. Supervisi berlangsung dalam suatu tatapmuka yang terbuka 8

h. Supervisi berlangsung dalam satu siklus : kesimpulan/tindak lanjut dari latihan sebelumnya akan menjadi masukkan untuk perencanaan latihan berikutnya.

Terdapat beberapa perbedaan antara supervisi klinis dengan supervisi non klinis;

\begin{tabular}{|c|c|c|}
\hline ASPEK & SUPERVISI NON -KLINIS & SUPERVISI KLINIS \\
\hline $\begin{array}{l}\text { a. } \begin{array}{l}\text { Prakarsa dan tanggung } \\
\text { jawab }\end{array} \\
\text { jaw }\end{array}$ & Terutama oleh supervisor & $\begin{array}{l}\text { Diutamakan oleh calon } \\
\text { guru. }\end{array}$ \\
\hline $\begin{array}{l}\text { b. Hubungan supervisor-calon } \\
\text { guru }\end{array}$ & $\begin{array}{l}\text { Relasi guru-siswa atau } \\
\text { atasan-bawahan }\end{array}$ & $\begin{array}{l}\text { Relasi kolegial yg } \\
\text { sederajad dan interaktif. }\end{array}$ \\
\hline c. Sifat supervisi & $\begin{array}{l}\text { Cendrung direktif atau } \\
\text { otoritatif }\end{array}$ & $\begin{array}{l}\text { Bantuan yang } \\
\text { demokratis. }\end{array}$ \\
\hline d. Sasaran supervisi & $\begin{array}{l}\text { Samar-samar atau sesuai } \\
\text { keinginan supervisor } \\
\text { Umum dan Luas. }\end{array}$ & $\begin{array}{l}\text { Diajukan oleh calon guru } \\
\text { sesuai kebutuhannya. } \\
\text { Terbatas sesuai kontrak. }\end{array}$ \\
\hline e. Ruang Lingkup supervisi & Cendrung evaluatif. & $\begin{array}{l}\text { Bimbingan yang analitik } \\
\text { dan deskriftif. }\end{array}$ \\
\hline f. Tujuan supervisi & $\begin{array}{l}\text { Banyak memberi tahu dan } \\
\text { mengarahkan. }\end{array}$ & $\begin{array}{l}\text { Banyak bertanya untuk } \\
\text { membantu analisis diri. }\end{array}$ \\
\hline g.Peran supervisi dalam & Samar-samar atau atas & Dengan analisis dan \\
\hline $\begin{array}{l}\text { dalam pertemuan } \\
\text { h.Balikan }\end{array}$ & kesimpulan supervisor. & $\begin{array}{l}\text { interpretasi bersama atas } \\
\text { data observasi sesuai } \\
\text { kontrak. }\end{array}$ \\
\hline
\end{tabular}




\section{Prinsip-Prinsip Supervisi Klinis}

Terdapat sejumlah prinsip umum yang menjadi acuan didalam pelaksaan supervisi klinis, yang menjadi pedoman baik bagi supervisor maupun mahasiswa calon guru. Beberapa prinsip umum yang menjadi landasasan supervisi klinis tersebut diantaranya :

1. Hubungan antara supervisor dan calon guru adalah hubungan kolegial antar tenaga profesional yang lebih berpengalaman dan yang kurang berpengalaman memungkinkan suatu dialog yang terinteraktif dalam suatu suasana yang intim dan terbuka, dan bukan hanya pengarahan atau intruksi dari supervisor saja.

2. Pertemuan/diskusi antara supervesor dan calon guru adalah permusyawaratan yang demokratis, baik pada perencanaan latihan maupun pada pengkajian balikan dan tidak lanjut. Suasana demokratis itu dapat terwujud kalau kedua pihak dengan bebas mengemukakan pendapatdan tidakmendomminasi pembicaraan serta memilikisifat keterbukaan untuk mengkaji semua pendapat yang dikemukakan di dalam pertemuan tersebut dan pada akhirnya keputusan ditetapkan atas persetujuan bersama.

3. Sasaran supervisi terpusat pada kebutuhan dan aspirasimahasiswa calon guru, serta tetap berada dalam kawasan (ruang lingkup) tingkah laku guru dalam mengajar secara aktual. Dengan prinsip ini mahasiswa calon guru di doronguntuk menganalisis kebutuhan dan aspirasinya di dalam usaha mengembangkan dirinya.

4. Pengkajian balikan berdasarkan data observasi yang cermat yang didasarkan ataskontrak, serta dilaksanakan dengan segera. Dari hasil analisis balikan itulah ditetapkan rencana selanjutnya.

5. Mengutamakan prakarsa dan tanggung jawab mahasiswa calon guru, baik pada tahap perencanaan, pengkajian balikan, bahkan pengambilan keputusan dan tindak lanjut. Dengan mengalihkan sedini mungkin prakarsa dan tanggung jawab itu ketangan mahasiswa calon guru diharapkan pada gilirannya kelak dilapangan akan tetap mengambil prakarsa untuk mengembangkan dirinya.

Perwujudan prinsisp-prinsip tersebut di atas dalam pelaksanaan supervisi klinis membawa implikasi baik bagi supervisor maupun mahasiswa calon guru. Implikasi kepada supervisor antara lain : 
a. Yakin akan kemampuan calon guru untuk mengembangkan dirinya serta untuk memecahkan masalah yang dihadapinya.

b. Memiliki sikap terbuka dan tanggap terhadap setiap pendapat calon guru.

c. Mau dan mampu memperlakukan mahasiswa calon guru sebagai kolega yang memerlukan bantuannya. Sedang implikasi bagi mahasiswa calon guru, seperti: (1) perubahan sikap dari "mahasiswa" menjadi "guru" yang mau dan mampu mengambil prakarsa untuk menganalisis dan mengembangkan dirinya, dan (2) bersikap terbuka dan obyektif dalam menganalisis dirinya. Di samping itu kedua pihak harus menguasai konsep dasar dan prosedur supervisi klinis, sedang supervisorharus pula menguasai teknik-teknik dalam proses pembimbingan dengan pendekatan /model supervisi klinis.

\section{E. Prosedur Supervisi Klinis}

Supervisi klinis dilaksanakan menurut suatu prosedur tertentu, yakni suatu rangkaian langkah-langkah yang akan ditempuh pada waktu melaksanakan sepervisi klinis. Terdapat berbagai variasi pendapat tentang prosedur supervisi itu, tetapi pada prinsipnya mempunyai persamaan. Menurut AR. Effendi (1993:10) mengatakan bahwa prosedur dalam supervisi klinis meliputi "perencanaan, observasi mengajar, diskusi balikan dan tindak lanjut". Supervisi klinis yang berlangsung dalam suatu siklus dengan tiga tahap beserta kegiatan-kegiatan dalam setiap tahapnya dapat dilihat sebagai berikut:

1. Tahap pertemuan awal,yakni pertemuan yang diadakan atas permintaanmahasiswa calon guru setelah ia menyusun rencana latihannya yang meliputi desain intruksional dan tujuan latihan itu sendiri. Pada tahap ini terdapat beberapa kegiatan penting, seperti :

- Menciptakan suasana pertemuan yang intim dan terbuka,

- Mengkaji rencana pembelajaran, yang meliputi tujuan, metode, evaluasi hasil belajar dan lain-lain yang berkaitan dengan kegiatan pembelajaran yang akan dilaksanakan itu,

- Mengkaji keterampilan-keterampilan mengajar yang akan dilatihkan itu, erutama indikator-indikatornya,

- Memilih atau mengembangkaninstrumen observasi yang akan dipakai mengobservasi calon guru yang sedang mengajar, 
- Menegaskan kembali kesimpulan pengkajian dalam tahap ini untuk menjadi kesepakatan (kontrak latihan).

2. Tahap observasi mengajar, yakni mahasiswa calon guru mengajar, dan diobservasi sesuai dengan kontrak latihan.

3. Tahap pertemuan akhir,yakni pertemuan yang harus dilakukan dengan segera setelah latihan mengajar, agar persepsi tentang kegiatan pembelajaran masih segar dalam ingatan kedua belah pihak. Di dalam pertemuan ini dikaji bersama data yang telah direkam dengan instrumen yang telah disepakati pada tahap pertemuan awal.Kegiatan pokok dalam tahap ini antaralain :

- Memberi penguatan,serta menanyakan pendapat/ perasaan calon gurusecara umum tentang latihannya, agar diusahakan suatu suasana santai,agarcalon guru tidak merasa diperiksa/diadili, sehingga dengan bebas mengkaji dirinya;

- Meriviu tujuan pengajaran;

- Meriviu target kontrak latihan;

- Mengkaji/menganalisis data hasil observasi dan dengan batuan supervisor, calon guru berusaha menginterpretasi dan menyimpulkan data hasil observasi itu;

- Menanyakan pendapat calon guru tentang kegiatan pembelajaran yang telah dilakukan, terutama dilihat dari segi tujuan pengajaran dan tujuan latihannya;

- Menetapkan tindak lanjut serta rencana latihan berikutnya.

Demikian garis besar ketiga tahap dalam prosedur supervisi klinis yang merupakan suatu siklus, karena akhir dari tahap ketiga merupakan persiapan untuk tahap pertama pada latihan berikutnya. Perlu ditekankan bahwa kegiatan-kegiatan supervisor dalam setiap tahap tersebut haruslah dijiwai oleh prinsip-prinsip supervisi klinis, agarsecara serentak dapat dikembangkan kemampuan dan sikap profesional calon guru.

\section{F. Instrumen Supervisi Klinis}

Taufik Sabirin (2009 : 4) instrumen supervisi klinis terdiri dari beberapa bagian. Pertama lembaran kesepakatan yang terdiri dari 4 aspek yakni : aspek kependidikan, akademik, pengelolaan kelas dan interaksi dengan siswa dalam proses pembelajaran. Dalam lembaran ini disepakati, apa fokus persoalan yang akan disupervisi. Kedua lembaran perangkat dan mediapembelajaran 
yang menjadi pilihan. Ketiga lembaran observasi, refleksi dan kesimpulan diskusi sebagai balikan. Keempat lembaran penutup, yang berisi saran pembinaan dan legalitas kegiatan.

Instrumen ini sifatnya terbuka dan setelah digunakan harus dimiliki oleh calon guru yang disupervisi dan supervisor dalam hal ini guru pamong atau dosen pembimbing. Karena data, fakta dan kesimpulan yang terdapat dalaminstrumen ini yang akan dijadikan dasar dalam perencanaan kegiatan siklus selanjutnya.

\section{G. Organisasi Pelaksana Supervisi Klinis}

Supervisi klinis dapat menjadi salah satu bentuk alaternatif darisekian banyak alternatif. Hal ini dimungkinkan karena supervisis klinis tidak membutuhkan struktur organisasi yang rumit dan dapat dilaksanakan dengan anggaran yang relatif kecil, tetapi dapat menyentuh persoalan besar yakni peningkatan keterampilancalon guru dalam mengelola pembelajaran di dalam kelas. Upaya peningkatan mutu pendidikan hanya akan menjadi ilusi kalau peningkatan proses pembelajaran dalam kelas tidak terwujud secara berkelanjutan.

Pelaksanaan supervisi klinis dalam Program Pengalaman Lapangan (PPL) direalisasikan dengan membentuk beberapa tim yaitu, tim dari pihak sekolah tempat calon guru berpraktek ( guru pamong, koordinator guru pamong atau kepala sekolah), tim dari unit UPT PPL, tim dari jurusan atau dari program studi.

Tim ini dibekali panduan khusus untuk memberikan bekal keterampilan kepada calon guru dan tim ini bertanggung jawab kepada Dekan Fakultas Keguruan dan Ilmu Pendidikan.

\section{H. Permasalahan dan Alternatif pemecahan}

Pelaksanaan supervisi klinis, yang secara konsepsional memberipeluang akan terciptanya iklimyang kondusif bagi kebehasilan pembimbingan (pembimbingan calon guru), tidak selamanya dapat berjalan seperti yang kita harapkan. Seperti yang telah dikemukakan kelancaran proses supervisi klinis didukung oleh beberapa syarat, antara lain: adanya hubungan yang kolegial, kesamaan persepsi terhadap permasalahan yang dihadapi, kepemimpinan pembimbing yang efektif, kemampuan dan kemauan pembimbing untuk mengutamakan kepentingan calon guru serta bersikap konstruktif serta 
kesewdiaan calon guru untuk belajar, bersikap terbuka, dan kemampuan menganalisis dan mengevaluasi dirinya.

Ketidak hadiran atau tidak terpenuhinya syarat-syarat tersebut akan menghambat keberhasilan pembimbingan dengan pendekatan supervisi klinis.

\section{Pola Hubungan yang Tidak Kolegial atau Kurang Intim}

Pola hubungan ini secara naluriah berkembang apabila pembimbing menempatkan diri sebagai supervisor dan menganggap mahasiswa calon guru sebagai bawahannya. Keputusan-keputusan yang diambil oleh pembimbing harus diterimaoleh mahasiswa calon gurudan harus dilaksnakan secara terpaksa.

Alternatif pemecahannya antara lain:

a. Jauh sebelumnya pembimbing berupaya melepaskan statusnya sebagai atasan dan bersikap serta memandang mahsiswa calon guru sebagai koleganya.Pembimbing harus dapat menerima calon guru secara akrab, hangat, kekeluargaan dan terbuka dengan tujuan agar mahasiswa merasa aman, tidaktakut dan minder,serta berani menampakkan jati dirinya dan tidak berpura-pura.

b. Dipihak mahasiswa calon guru perlu dikembangkan sikap terbuka, tidak perlu menyembunyikan kekurangannya, dan beranggapan bahwa pembimbing merupakan kolega seprofesi yang memiliki pengalaman banyak dan berfungsi membantu dirinya.

c. Situasi dan kondisi pada tahap perkenalan perlu dipersiapkan sedemikian rupa sehingga hubungan antara pembimbing tidak ada jarak yang dapat menumbuhkan sikap superior dan inferior.

2. Perbedaan Persepsi antara pembimbing (Guru Pamong/Dosen Pembimbing) dengan Mahasiswa Calon Guru.

Perbedaan persepsi antara pembimbing dengan mahasiswa calon guru terhadap masalah yang mereka hadapi pasti akan terjadi dan wajar, karena perbedaan latar khasanah pengetahuan dan pengalaman masingmasing individu. Perbedaan-perbedaan ini menjadi sumber konflik yang menghambat kelancaran proses pembimbingan.

Alternatif pemecahannya antara lain:

a. Masing-masing pihak perlu mengembangkan kemampuan memahami apa dan bagaimana cara berfikir dan perasaan orang lain dalam menghadapi suatu masalah. Dengan modal kemampuan ini proses 
pengambilan keputusan dengan bimbingan guru pamong/dosen pembimbingcendrung mencapai titik konsesusyang dapat mereka sepakati.

b. Perbedaan persepsi antara pembimbing dan mahasiswa calon guru dapat dikurangi apabila mereka memiliki wawasan yang relatif sama. Hal ini dapat terwujud apabila program PPL direncanakan dan dilaksanakan secara terpadu antara kampus dan sekolah.

c. Konflik dapat dikurangi, apabila masing-masing pihak bersikap, berfikir dan mengambilkeputusan secara objektif. Meskipun proses kejadiannya tidak mungkin $100 \%$ abjektif, sikap, berfikir, dan proses pengambilan keputusanyang obyektif cendrung mengarah pada suatu konsensus yang dapat dipertanggu jawabkan.

3. Kepemimpinan Pembimbing yang Kurang Efektif

Kepemimpinan pembimbing yang kurang efektif akan menghambat kelancaran proses supervisi. Kepemimpinan bearti kemampuan pembimbing mempengaruhi dan mengarahkan mahasiswa calon guru dalam proses supervisi.

Alternatif Pemecahannya antara lain :

a. Pembimbing harus memiliki kewibawaan dalam arti kelebihan kemampuannya sebagai pembimbing diakui oleh mahasiswa calon guru secara ikhlas. Pengakuan ini tumbuh apa bila pembimbing memiliki kemampuan personal, profesional dan sosial yang relevan dengan fungsi dan tugasnya sebagai supervisor.

b. Pembimbing dapat menerapkan gaya kepemimpinan yang relevan dengan sistuasi dan kondisi proses supervisi, terutama relevan dengan tingkat kemampuan dan kemauan (semangat kerja) mahasiswa calon guru.

4. Kemampuan dan kemauan pembimbing yang kurang memadai.

Kemampuan dan kemauan pembimbing merupakan potensi yang harusada dalam prosessupervisi, karena kedua-duanya saling berpengaruh terhadap keberhasilan proses supervisi. Oleh karena itu pembimbing perlu memiliki atau menguasai:

a. Kemampuan-kemampuan :

- Konseptentang supervisi klinis, proses belajar mengajar, bidang studi dan psikologi pendidikan 
- Bebrbagai teknik, baik teknik supervisi maupun keterampilan dasar mengajar.

b. Motivasi untukmelaksanakan fungsidan tugasnya sebagai supervisor. Ia harus bangga sebagai supervisor, marasa bahagia bila upayanya berhasil, mendapatkan penghargaan yang wajar terhadap hasil usahanya serta memiliki prospekyang jelas dan menyenangkan terhadapmasa depannya.

5. Kesediaan dan Semangat Belajar Mahasiswa Calon Guruyang Kurang Kesediaan dan semangat belajar mahasiswa calon guru yang kurang, mewarnai intensitas kualitas proses interaksi. Semangat belajar calon guru berkembang apabila :

a. Ia diperlakukan sebagai, manusia dengan segala kelemahan dan kekuatan yang ia miliki.

b. Ia mengerti dan menyadri bahwa proses supervisi dapat memenuhi kebutan belajarnya.

c. Ia dapat melihat tujuan supervisi secara jelas

d. Ia merasakan bahwa supervisi ada manfaatnya bagi perkembangan personal dan sosialnya.

6. Keterbatasan Kemampuan Mahasiswa Calon Guru Menganalisis dan mengevaluasi Diri

Keterbatasan kemampuan mahasiswa calon guru menganalisis dan mengevaluasi diri merupakan hal yang wajar. Akan tetapi hal ini merupakan tugas bagi supervisor untuk mengembangkan pola interaksi supervisi yang dilaksanakan. Perubahan prilaku mahasiswa calon guru dipengaruhi kemampuan kemampuan mahasiswa calon guru mengevaluasi dirinya secara obyektif. Untuk itu supervisor harus dapat mengwujudkan respon-responnya sebagai reflektor prilaku mahasiswa calon gurusecara obyektif.

\section{Penutup}

Implementasi supervisi klinis menuntut persyaratan tentang pengetahuan, keterampilan dansikap tertentu dari semua pihakyang terkait di dalam pelaksanaan PPL (dosen pembimbing, guru pamong dan mahasiswa calon guru). Disamping itu perlu didukung iklimkelembagaanyang kondusif, utamnya iklim profesional yang terbuka dan obyektif. Oleh karena itu, diperlukan bukan hanya penyiapan terhadap pembimbing (dosen pembimbing 
dan guru pamong) dan mahasiswa calon guru, tetapi juga pihak lain yang terkait dengan pelaksanaan PPL (utamnya aspek pembimbingan) yakni program studi, serta kepala sekolah dan pengawas di sekolah latihan yang bersangkutan. Sebgaimana kita ketahui penciptaan iklim profesional tersebut memerlukan pembinaan yang terus menerus dalamwaktuyang lama. Hal ini hanya dapat dilakukan apabilasekolah tempat latihan relatif tetap,sekolah yang telah ditetapkan sebagai sekolah mitra.

Disamping aspek personal dan institusional, perlu pula dukungan sistematik yang kondusif, khususnya yang berkenaan dengan kelancaran kerja sama antara sekolah dengan program studi. Sebagai contoh diperlukan pengaturan khusus. Sehingga pembinaan personal dapat dilakukan bersama, baik terhadap dosen pembimbing dan mahasiswa maupun terhadap guru pamong, kepala sekolah dan pengawas. Seperti telah dikemukakan bahwa diperlukan kelancaran kerja sama dengan meminimalkan hambatan birokrasi, namun dalambatasankewenangan kelembagaan masing-masing. Dukungan yang sistematik yang kondusiftersebut akan memberikan peluang keberhasilan pelaksanaan supervisi klinis dengan semestinya.

\section{DAFTAR PUSTAKA}

AR. Effendi (1993) Supervisi Klinis, Malang: IKIP Malang Bolla. JI (1985) Supervisi Klinis, Jakarta: P2LPTK Depdikbud Brown (1975) Microteaching: A Program of Teaching, Skills, London: Mathuen

Sulo Lasulo (1983) Pendekatan dan Teknik-teknik Supervisi Klinis. Jakarta: P2LPTK

-------- (1983) Supervisi Klinis, Jakarta: Dirjen Dikti

Taufik Sabirin (2009), Peningkatan Kualitas Pembelajaran di Kelas Melalui Supervisi Klinis, http:/taufiksabirin.wordprees.com.

Ike Kusdiyah Rachmawati (2008) Manajemen Sumber daya Manusia, Yoyakarta: Andi. 